\title{
Introduction: Entrepreneurship and Industrial Organization
}

\author{
David B. Audretsch ${ }^{1}$ - Albert N. Link ${ }^{2}$ - Erik E. Lehmann ${ }^{3}$ \\ Published online: 18 July 2020 \\ (c) Springer Science+Business Media, LLC, part of Springer Nature 2020
}

\begin{abstract}
The purpose of this paper is to introduce the special issue of the Review of Industrial Organization on "Entrepreneurship and Industrial Organization" by highlighting the important ways that the literatures of industrial organization and entrepreneurship are highly intertwined. The paper concludes that the two literatures are indeed closely related and complementary.
\end{abstract}

Keywords Entrepreneurship · Innovation · Market entry

\section{Introduction}

At first glance it would seem that the literatures of industrial organization and entrepreneurship are not only distinct but have very little overlap or even relevance to each other. The purpose of this special issue is to argue that this is not the case and that, in fact, the literatures of industrial organization and entrepreneurship are highly intertwined.

In the second section of this paper, three main themes that link the literatures of industrial organization and entrepreneurship are explicitly identified and explained. In particular, these themes involve entry, innovation, and competition. In the third section of the paper, how each of the individual contributions to the special issue are related to at least one of these themes is explicitly identified and explained. Finally, in the last section of the paper, a summary and conclusion are provided.

Albert N. Link

anlink@uncg.edu

David B. Audretsch

daudrets@indiana.edu

Erik E. Lehmann

erik.lehmann@wiwi.uni-augsburg.de

1 Indiana University, Bloomington, USA

2 University of North Carolina at Greensboro, Greensboro, USA

3 University of Augsburg, Augsburg, Germany 
In particular, this paper finds that because of the central role that is played by the themes of entry, innovation, and competition, the fields of industrial organization and entrepreneurship are not just interrelated but are also highly complementary.

\section{Linking Entrepreneurship to Industrial Organization}

There are at least three important ways that entrepreneurship intersects with industrial organization: entry, innovation, and competition. Entry is central to industrial organization because it provides the mechanism that restores markets to zero-profit equilibrium. Dating back at least to the seminal work of Bain (1956), entry was viewed in the literature of industrial organization as the key mechanism that would increase output to levels that are consistent with zero profits in long-run equilibrium. In the absence of barriers to entry, positive economic profits would be eroded through the increase in output that is provided by the entrants, restoring long-run equilibrium in the market (Sutton 1991).

The notion of entry into markets does not specify who or which type of firm actually constitutes that entrant. Entrants could take the form of incumbents that expand production into new product or geographic markets. By contrast, de novo entry suggests entrepreneurial entry, where a newly created firm is the vehicle for entering the industry. While entrepreneurial firms are de facto entrants into an industry, not all entrants are entrepreneurial firms. Which organizational form plays a more important role for entry has been an important focus for research in the industrial organization literature (Audretsch 1995). In some contexts, de novo entry plays a more important role in the organization of industries, while in others entry from incumbents is the predominant organizational form (Gort and Klepper 1982).

A second important interface between industrial organization and entrepreneurship involves innovation (Audretsch and Link 2019; Link 2017; Link et al. 2020): Dating back to at least Schumpeter (1942) and Chandler (1990), the size of a firm was viewed in the literature of industrial organization to be conducive to innovative activity (Scherer and Ross 1990). The knowledge production function model of innovation linked knowledge inputs-such as human capital and research and development (R\&D)— to innovative output (Griliches 1979). Scale economies and size have been consistently linked to R\&D investments, therefore bestowing large firms with an inherent size-related innovative advantage. However, the literature of industrial organization found exactly the opposite, that small and new firms are remarkably innovative despite a paucity of investments in R\&D and human capital (Acs and Audretsch 1990).

The entrepreneurship literature provided a resolution to the paradox of robust new and small firm innovative activity despite having limited R\&D investments. The knowledge spillover theory of entrepreneurship (Audretsch 1995; Audretsch et al. 2006) suggests that new and small firm innovation is the result of entrepreneurial firms' being started as a conduit for the spillover of knowledge that is created in one organizational context but is actually commercialized and transformed into innovation through the formation of a new firm, which ultimately provides the vehicle for market entry. 
A third way in which entrepreneurship intersects with industrial organization is through competition. Entrepreneurship generally increases both the number of firms in the market as well as introducing new products and variety through innovative activity. As Audretsch et al. (2001) point out, entrepreneurship generally enhances the extent of competition in markets, so that entrepreneurship policies may be overlooked as the sleeping giant of antitrust and competition policy.

\section{Contents and Contributions}

The papers that are included in this special issue generally touch upon the three main intersections between industrial organization and entrepreneurship. In "The Economic Contribution of a Cohort of New Firms Over Time," Alex Coad, Julian S. Frankish and Albert N. Link focus on the first topic: entrepreneurship as a vehicle for market entry. In particular, their paper provides one of the first studies to analyze the impact of entrepreneurial entrants in terms of their market impact, as measured by sales. While most of the extant literature focuses on impact at the time of entry, an important and novel contribution of Coad, Frankish, and Link is to consider the actual impact of those entrepreneurial startups in terms of market penetration over time.

Sameeksha Desai, Johan E. Eklund, and Emma Lappi combine a focus on the first theme-the intersection between industrial organization and entrepreneurship via entry - with the third theme: competition. In "Entry Regulation and the Persistence of Profits in Incumbent Firms," Desai, Eklund, and Lappi revisit an important strand of the industrial organization literature that focuses on the persistence of profits by firms; but the authors introduce the role of entrepreneurship and entry regulations. In particular, they find that entry regulation is conducive to the persistence of profits by incumbent firms and that entry does not necessarily dissipate economic profits.

In "Entrepreneurial Firms: With Whom Do They Compete, and Where?" Marc Cowling and Simon Nadeem focus on the third theme that links industrial organization to entrepreneurship: competition. In particular, they analyze the types of market structure in which small firms compete and their impact on market competition.

Jürgen Antony and Torben Klarl provide a focus on the second topic that links industrial organization and entrepreneurship, innovation. In "Knowledge Transfer, Transitional Dynamics and Optimal Research and Development Policy in a Dynamic Monopoly Setting," they address the issue of whether reducing barriers to knowledge enhances investments in $R \& D$. In their model of firm learning they show that there is no unambiguous answer but rather that the exact impact of knowledge barriers on R\&D depends upon a number of the basic conditions of industrial organization that characterizes the particular market.

The final paper of the special issue addresses the first theme that links industrial organization to entrepreneurship: entry. In "Does a Guaranteed Basic Income Encourage Entrepreneurship? Evidence from Alaska" Robert M. Feinberg and Daniel Kuehn analyze how changes in the guaranteed basic income (GBI) - or what is sometimes referred to as a universal basic income-influence entry in the form of entrepreneurship. Feinberg and Kuehn analyze data at both the level of the 
individual and the state, and they find that the implementation of the Alaska Permanent Fund Dividend Program generally enhanced entry through entrepreneurial startups.

\section{Conclusions}

Taken together, the papers in this special issue highlight some of the most salient ways that the literatures of industrial organization and entrepreneurship intersect and reinforce each other. In particular, three central themes link the literatures of industrial organization and entrepreneurship: entry, innovation, and competition. Just as industrial organization cannot be fully understood without incorporating not just the impact of entrepreneurship but also many of the concepts and methods that are prevalent in the entrepreneurship literature, so too can entrepreneurship not be fully understood or analyzed without taking the context of the organization of the industry into account. These papers highlight the contribution that each of these fieldsindustrial organization and entrepreneurship_-make in helping the other to advance.

\section{References}

Acs, Z. J., \& Audretsch, D. B. (1990). Innovation and small firms. Cambridge: MIT Press.

Audretsch, D. B. (1995). Innovation and industry evolution. Cambridge: MIT Press.

Audretsch, D. B., Baumol, W., \& Burke, A. (2001). Competition policy in dynamic markets. International Journal of Industrial Organization, 29(5), 613-634.

Audretsch, D. B., Keilbach, M., \& Lehmann, E. E. (2006). Innovation and industry evolution. New York: Oxford University Press.

Audretsch, D. B., \& Link, A. N. (2019). Sources of knowledge and entrepreneurial behavior. Toronto: University of Toronto Press.

Bain, J. S. (1956). Barriers to new competition. Cambridge: Harvard University Press.

Chandler, A. D. Jr. (1990). Scale and scope. Cambridge: Harvard University Press.

Gort, M., \& Klepper, S. (1982). Time paths in the diffusion of product innovations. Economic Journal, 92(367), 630-653.

Griliches, Z. (1979). Issues in assessing the contribution of research and development to productivity growth. Bell Journal of Economics, 10, 92-116.

Link, A. N. (2017). Ideation, entrepreneurship and innovation. Small Business Economics, 48(2), 279-285.

Link, A. N., Morris, C. A., \& van Hasselt, M. (2020). The impact of the third sector of R\&D on the innovative performance of entrepreneurial firms. Small Business Economics. https://doi.org/https://doi. org/10.1007/s11187-020-00354-8.

Scherer, F. M., \& Ross, D. (1990). Industrial market structure and economic performance. Boston: Houghton Mifflin.

Schumpeter, J. A. (1942). Capitalism, socialism and democracy. New York: Harper and Row.

Sutton, J. (1991). Sunk costs and market structure. Cambridge: MIT Press.

Publisher's Note Springer Nature remains neutral with regard to jurisdictional claims in published maps and institutional affiliations 